\title{
Can community-based adaptation increase resilience?
}

\author{
J. Ensora, S.E. Park ${ }^{b}$, S.J. Attwood ${ }^{c}$, A.M. Kaminskid ${ }^{\text {, J.E. Johnsone }}$
}

a Stockholm Environment Institute, Environment Department, University of York, Heslington, York Y010 5DD, UK.

b SciDev Consulting.

c Bioversity International, Via dei Tre Denari, 472/a, 00057 Maccarese, Italy. d WorldFish, Katima Mulilo Road, Plot No. 37417, Olympia Park, Lusaka, Zambia. e $\mathrm{C}_{2} \mathrm{O}$ coasts climate oceans, Cairns, Australia, \& College of Marine and Environmental Sciences, James Cook University, Cairns, Australia.

A central claim of community-based adaptation (CBA) is that it increases resilience. Yet, the concept of resilience is treated inconsistently in CBA, obscuring discussion of the limitations and benefits of resilience thinking and undermining evaluation of resilience outcomes in target communities. This paper examines different participatory assessment activities carried out as part of CBA case studies in Timor-Leste and Solomon Islands. The activities and their outputs were assessed against ten characteristics of resilience previously identified in a systematic review. The findings offer support to the claim that CBA can build resilience in target communities, revealing the inherent strengths of CBA in relation to resilience. However, it is necessary for CBA assessments to simultaneously incorporate activities that consider cultural, political, economic and ecological factors influencing resilience within and between communities. This may demand multiple staff with different skills. The findings also highlight the importance of politics and power in shaping adaptive capacity. In particular, addressing the highly context specific nature of social, cultural and political relations demands an approach that is situated in and responsive to local realities. Overall, our case study suggests that using the ten characteristics as an analytical framework offers support to practitioners looking to develop, implement or evaluate CBA assessment activities. Yet within this, it is critical that a focus on increasing resilience through CBA does not preclude transformation in social relations. Realising the potential to support resilience and transformation requires CBA practitioners to acknowledge the multifaceted nature of resilience, whilst also paying close attention to multiple potential barriers to equitable adaptation.

Keywords: community-based adaptation, climate change, participation, fisheries

\section{Introduction}

For many international development non-governmental organisations (NGOs), climate change emerged as an issue in concerns raised by communities with which they worked. Field staff observed that changes to seasonal weather patterns and extreme events were rendering rural communities increasingly unable to rely on traditional livelihood practices, such as planting calendars, pest/disease control methods, or animal husbandry (Ensor and Berger, 2009). 
In response, community-based adaptation (CBA) interventions, which sought to address climate change through grass-roots development interventions, began to form part of development practice. Rooted in the evolving praxis of Participatory Learning and Action (PLA) and Participatory Action Research (PAR), CBA interventions typically draw on Participatory Rural Appraisal (PRA) and Rapid Rural Appraisal (RRA) methods to understand the impact of climate change, the social and ecological context, and the efficacy of potential adaptation interventions (Ensor et al. 2014; Reid et al. 2009). The rise of interest in CBA among practitioners (Ensor, 2014; Ensor and Berger, 2009; Mitchell and Tanner, 2006; Schipper et al., 2014) has been mirrored in recent years by an increasing body of critical reflections in the academic literature (Dodman and Mitlin, 2011; Forsyth, 2013; Spires et al., 2014). For many, a central claim of CBA is that it increases resilience (Ayers and Forsyth, 2009; Forsyth, 2013; Heltberg et al., 2012; Simane, 2013). In this paper the focus is on testing this claim, using an approach that can be adopted by practitioners and applied to a broad range of development activities claiming to build resilience. Analysis focuses on activities included in the diagnostic and planning phase of CBA interventions. It is during this phase that the application of numerous PRA and RRA methods narrow the scope of the adaptation challenge in a given context, first by providing an understanding of the likely impacts of climate change on livelihoods, and second by selecting and evaluating potential adaptation options. These findings are then synthesised to propose an adaptation strategy. While recognising the different lineages and usages of the term resilience (Bahadur et al., 2013; Béné et al., 2014) and applications of CBA (for example, human health (Ebi and Semenza, 2008), disaster risk management (Shaw 2006) and biodiversity and sustainable natural resource management (Muang et al., 2013)), in this paper the practice of CBA in international development is examined in relation to social-ecological resilience, or the capacity of social-ecological systems to continue to provide the goods and services that support a desirable quality of life in the face of external disturbances (Walker and Salt, 2006).

CBA has been defined as "a community-led process, based on communities' priorities, needs, knowledge and capacities" (Reid et al., 2009). As such, it is a participatory approach to adaptation that requires practitioners to explore climate change impacts and responses in partnership with communities. Recent academic work has refined understanding of CBA and identified critical issues for implementation. Significance is placed on methods capable of eliciting local knowledge and understanding of the complex relationship between climate change hazards and livelihoods (Pringle and Conway, 2012) and on avoiding barriers to adaptation that arise from poor communication between those with different knowledge systems (e.g. between those who create and those who use climate information) (Spires et al., 2014). Butler et al. (2013) reflect practitioner experience (e.g. Reid et al., 2009) in emphasising that climate change is only one cause of vulnerability in a particular context, inseparable from cultural, political, economic, environmental and development factors. This in turn underpins the need for "multiple and integrated adaptation measures" that look beyond technological responses, to include all relevant sectors and institutions in adaptation actions (Rawlani and Sovacool, 2011). Studies of the politics of CBA go further. This literature recognises, first, that the drivers of vulnerability are 
national and regional as well as local (Dodman and Mitlin, 2011; Forsyth, 2013); and second, that cultural and power relations shape how local risks are understood, prioritised and managed in adaptation decision making processes (Artur and Hilhorst, 2012; Ayers, 2011; Granderson, 2014; Yates, 2012). These findings draw attention to the complexity of the setting in which CBA interventions take place, and the challenges that this presents for practitioners. Significantly, these considerations are essential not only for project efficiency or efficacy, but because interventions may yield unexpected and inequitable outcomes if the broader social, cultural and political environment is overlooked.

This context is central to the ambition that CBA works with communities in ways that "empower them to make changes themselves" (Reid et al., 2009). This focus on empowerment and the development process, over and above the provisioning of particular adaptation technologies, brings adaptive capacity and, in turn, resilience to the centre of CBA. Adaptive capacity represents the ability of actors to shape or create deliberate changes in anticipation of, or in response to, external disturbances (Chapin et al., 2006). As such, adaptive capacity describes the ability of actors to influence resilience through the enactment of adaptations, comprising both social and physical elements and the ability to mobilize them (Nelson et al., 2007; Smit and Wandel, 2006). A growing body of literature focuses on identifying specific social and economic dimensions of adaptive capacity (Marshall et al., 2013; Wise et al., 2014) and how politics and power relations shape adaptive capacity (and thereby resilience) via access to and control over resources and decision making (Dodman and Mitlin, 2014; Ensor et al., 2015).

While there are frequent references to resilience and resilience building in the CBA literature, definitions are varied (Forsyth, 2013) and occasionally absent (e.g. Rawlani and Sovacool, 2011). Resilience building is most commonly described in broad terms, as the ability to cope (Simane, 2013), or to deal with risk (Reid et al., 2009) or a wide range of shocks and stresses (Dodman and Mitlin, 2011) in the face of uncertainty. Elsewhere, the emphasis is placed on addressing underlying social vulnerability (Ayers and Forsyth, 2009) or, in stark contrast, reinforcing infrastructure (as discussed by Forsyth, 2013). In practice, many attempts at resilience building look to diversify livelihoods, reflecting a focus on coping, but with little explicit attention paid to the social and political determinants of adaptive capacity, or the need to effect future adaptations in response to emerging climate change (Ensor and Berger, 2009; Ludi et al., 2012). While recent reports from practitioners suggest a shift towards development focus on adaptive capacity and its determinants, the relationship to resilience continues to be overlooked or poorly defined (Berger et al., 2014; Ensor, 2014; Ludi et al., 2014). Thus, despite moving to the centre of policy and practice debates in recent years (Brown, 2014; Frankenberger et al., 2014), resilience remains at best a "moving target" (Béné et al., 2014) for CBA.

This lack of clarity around resilience undermines opportunities for critical reflection on the purpose and practice of CBA in two important ways. First, it is possible that significant contributions from resilience thinking are being overlooked in how CBA is understood and interventions are designed. Second, 
inadequate or inconsistent definitions of resilience prevent assessment of the extent to which claims of resilience building through CBA are being met. In this paper we aim to address these shortcomings, offering an analytical approach that practitioners can readily adopt to explore resilience building in development practice. We rely on the results of a recent systematic review, published in Climate and Development, to establish ten characteristics of resilience (Bahadur et al., 2013). We introduce these in the next section, alongside critiques and potential limitations of resilience in social-ecological systems that are found in the literature. Next we present three case studies of CBA in aquatic agricultural systems in Timor-Leste and Solomon Islands, analysing the contribution of the PRA tools and methods used towards each of the ten characteristics of resilience. In the discussion we emphasise the potential of CBA to build resilience and the particular significance of using a combination of tools to address the social and ecological setting. In closing, we propose that an explicit integration of resilience thinking into CBA and closer attention to structural and historical-cultural barriers to equitable adaptation actions are necessary if resilience is to be a progressive framing for CBA.

\section{Adaptation and resilience}

The systematic review conducted by Bahadur et al. (2013) represents an attempt to better define the value of resilience thinking to climate change adaptation. The focus of the review recognises and reflects the shift towards socialecological systems as the context for discussions of resilience in the social sciences (Walker et al., 2006), and the natural fit between social-ecological systems and development. This is equally the case for CBA, as the "vast majority of the world population across rural, urban and peri-urban areas most vulnerable to climate change impacts and disasters, directly relies on ecological services for livelihoods and wellbeing" (Bahadur et al., 2013). A resilience perspective shifts thinking away from viewing adaptation as the provision of solutions to well-defined problems, and towards adjustments that "sustain and enhance the capacity of social-ecological systems to cope with, adapt to, and shape change and learn to live with uncertainty and surprise" (Folke, 2003).

Drawing on literature related to society, ecology and social-ecological systems, Bahadur et al. (2013) distilled ten characteristics of resilience, summarised in Table 1. Bahadur et al. relied on a systematic review process consisting of three stages. First they developed a relevant objective for the review through wide consultation with colleagues engaged in research on climate change, disasters and resilience. They then determined key search terms (e.g. 'resilience', 'climate change resilience', 'social resilience', 'disaster resilience', 'socio-ecological systems') to identify literature in academic journal databases and indexes. The selected literature was then further refined using exponential discriminative snowball sampling. This narrowed the focus on resilience in the context of society, ecology, SESs, climate change and disasters. The refined selection of literature was then systematically analysed using a criterion that focused on definitions of resilience, its characteristics, components and any discussion on the interplay of resilience with concepts of vulnerability and adaptive capacity. This systematic review process produced a set of 10 characteristics common to the selected body of literature. Whilst Bahadur et al., recognize potential 
limitations of their method (for example, the potential for some influential papers to be overlooked; the subjective appraisal of the authors in identifying the characteristics), the study offers one of the first attempts to characterize the attributes of resilience in a way that are readily applicable to the practitioner community.

The ten characteristics identified by Bahadur et al. reflect key system attributes: the significance of cross-scale relationships, the different temporal scales at which system dynamics operate and the potential for non-linear or abrupt changes to take place in response to disturbances. They also engage with how individual, household or community adaptive capacity drives resilience in key ways, including the ability to: learn to live with change and uncertainty; nurture diversity for system reorganisation and renewal; combine different types of knowledge for learning; and, create opportunities for self-organisation (Brown and Westaway, 2011). Thus the characteristics drawn out include not only the nature of the complex systems setting (uncertainty and change, non-equilibrium system dynamics, cross-scale relationships), but also the conditions under which a resilience can emerge and be sustained (attributes relating to institutions and governance, knowledge systems, social capital and equity). These ten characteristics provide a framework for analysis of CBA in the following section.

Whilst a critical cross-analysis with more recent literature is outside the scope of this paper, it is notable that for the first characteristic (high diversity) there is recent support for including this characteristic from both ecological and management intervention perspectives. The role of ecological and functional diversity at various scales, in supporting resilience, has been noted by Angeler and Allen (2016). Furthermore, diversity at scales from landscape and seascape composition to local food systems is included in a recent toolkit intended to measure resilience indicators in social-ecological production systems (UNU-IAS, 2014). The diversity of available management responses has also been linked to increased resilience in the recent literature (e.g. Quinlan et al. 2015) and the development of a range of responses and interventions that cover a wide array of sectors (e.g. energy, agriculture, health, water, and infrastructure) has been noted in a toolkit intended to increase climate change resilience (IUCN 2014).

While recognising the rigour of the Bahadur et al. (2013) systematic review, recent critical literature has built on themes that suggest potential limitations of resilience as a framing for development actions. For CBA, it is important to acknowledge that a discourse of "community adaptation" can conceal the complex realities of local power relations (Ensor, 2014; Forsyth, 2013) and intracommunity variations in perceptions of risk and change (Granderson, 2014; Walker et al., 2014). Communities face multiple sources of vulnerability (Bennett et al., 2015) and focusing on securing 'place-based' resilience may be a mistake when networks of relationships beyond the local scale inform and sustain local (and, for some, undesirable) practices (Pauwelussen, 2016). Indeed, the selection of a particular focal scale will always serve to both reveal (for example, scale-specific qualities) and conceal (for example, marginalized or powerful actors at lower or higher scales) and as such must be critically engaged with in 
practice (Ingalls and Stedman, 2016). Resilience has also been critiqued as inherently conservative, by definition preferring the status quo in socialecological arrangements and, arguably, shifting the responsibility for coping with environmental change onto those least able to carry the burden and in so doing recreating unequal social relations (Robinson and Carson, 2015). Moreover, resilience says little about the relations of knowledge and power that inform its definition - it is "socially contingent, rarely addressing the question of 'resilience for whom'"' (Brown, 2014; Biermann, 2015). Cote and Nightingale (2012), for example, draw attention to how achieving resilience for some may come at a cost for others. These critiques provide an important reminder that CBA should not become a process of simply pursuing abstract resilience characteristics. Rather, it should look to embed resilience thinking into modes of development practice that can identify and address the local consequences of how politics, history and culture shape knowledge and power.

Social science and social theory provide critical tools for resilience in this regard (Biermann, 2015). The analytical framework of "path dependence" has been used to show that contemporary resilience can be significantly determined by social histories (Dagdeviren et al. 2015), adding to calls for "situated" resilience research that pays more attention to embedded socio-cultural relations, and less to checklists of predetermined characteristics that are to be embedded in or enacted through institutions (Cote and Nightingale, 2012). Indeed, resilience has been critiqued for assuming that purposeful, rational and optimal institutional design is possible, while overlooking insights into the politics and dynamics of institutional change that have emerged within the social sciences (Sjostedt, 2015). More broadly, the treatment of power within resilience has long been a source of criticism. Several scholars identify questions of procedural and distributional justice that are inevitably associated with the application of resilience, yet suggest that resilience narratives create "a cloud of obfuscation" around winners and losers and questions of "who is getting what" (Fainstein, 2015: 166). In particular, too much attention is paid to agency and not enough to how structural factors such as race, caste, markets and the state limit the potential for action (Dagdeviren et al. 2015), relocating responsibility to communities that are required to take "knock after knock", coping with and recovering from shocks (MacKinnon and Derickson, 2013: 255). Ingalls and Stedman (2016) draw on political ecology narratives to unpack the causes and effects of these unequal trade-offs, highlighting the need to interrogate and identify when and why different forms of knowledge are applied in resilience governance and decision making, and to recognize that it is relations of power that legitimize or undermine different problem framings and assessments of value.

One implication of this analysis is that development practice is often more concerned with the transformation of social conditions than with their resilience (Davies et al., 2015). Profound system transformation may result where interventions respond to the political context of adaptation, and work to empower marginalised communities and support collective action. These actions can challenge the structural and historical issues that underpin vulnerability, restrict access to or control over the resources needed for adaptation, or lock 
sections of society out of learning and decision making institutions (Ensor et al., 2015; O'Brien, 2012). Thus, for marginalized communities, building resilience may require going beyond coping, flexibility and incremental change, to engage with processes of transformation in social and political relations (Béné et al., 2014; Pelling, 2011).

Other critiques of resilience point to potential limitations arising from a neglect of the wider community development and individual psychology literature (Brown, 2014; Davidson, 2013). Community resilience focuses on selforganisation and individual and collective capacities. This literature explores forms of agency necessary for transformation, drawing particular attention to the potential role of power, competing interests and influence in shaping opportunities to exercise individual and collective agency (Ross and Berkes, 2013). While these factors may limit the ability of communities to make changes, this literature suggests that community resilience emerges in response to experiences of disasters and livelihood challenges (Berkes and Ross, 2013), and suggests that strategic, collective action underpins transformation of structural inequalities (Brown and Westaway, 2011). In the psychological literature, individual attributes (such as cognitive abilities and self-perception), relationships, and community resources (such as schools and good neighbourhoods) contribute to individual resilience, seen in coping with, recovering from, or thriving in response to, adversity (Brown and Westaway, 2011). Recent work has affirmed the role of individual well-being and identity in community resilience, recognising that well-being is underpinned by identification with a primary community, enhancing the ability of community members to cope (Miles, 2015). Shared cultural practices, such as those that support leadership, individual development and social networking, have been found to support resilience and transformation (Apgar et al. 2015). Yet attributes such as neighbourliness can also emerge in response to shocks, even when good relations were previously absent (Cheshire, 2015). Thus, attempts to assess the efficacy of CBAs to enhance resilience need to look to the individual, as well as the community, scale.

\section{Theory and Methods}

The review conducted by Bahadur et al., (2013) identified ten characteristics of resilience in social-ecological systems, as summarised in Table 1 . Their method drew on a well-established, robust and repeatable technique to systematically assess and synthesise findings. This approach is especially useful in developing a clear body of evidence for decision making, as required to support policy development (Mallett et al., 2012). As such, the study does not aim to define resilience, rather to identify and systematically classify common dimensions of resilience. Accepting the analytical rigor used by Bahadur et al., and in the absence of any substantial critiques to date, the ten characteristics offer a useful benchmark for practitioners to assess adaptation interventions for their capacity to build multiple dimensions of resilience. Here the approach is applied to activities conducted within three CBA case studies to consider the extent to which resilience is addressed. 
Table 1. Ten characteristics of social-ecological resilience (adapted from Bahadur et al., 2013)

\begin{tabular}{|c|c|}
\hline Characteristic & Summary description \\
\hline \multirow{3}{*}{ High diversity } & Diversity in ecosystems and economy \\
\hline & Variety of stakeholders engaged in processes \\
\hline & $\begin{array}{l}\text { Diversity of planning response and recovery } \\
\text { activities }\end{array}$ \\
\hline \multirow{3}{*}{$\begin{array}{l}\text { Effective governance and } \\
\text { institutions }\end{array}$} & Legitimate formal and informal structures \\
\hline & Flexible and responsive institutions \\
\hline & Enabling learning and experimentation \\
\hline \multirow{2}{*}{$\begin{array}{l}\text { Acceptance of uncertainty } \\
\text { and change }\end{array}$} & Systems that engage with and accept change \\
\hline & Flexibility rather than assumed linearity \\
\hline \multirow{3}{*}{$\begin{array}{l}\text { Non-equilibrium system } \\
\text { dynamics }\end{array}$} & Dynamism and change \\
\hline & Coping with, adapting to and shaping change \\
\hline & $\begin{array}{l}\text { Empowered individuals and institutions to } \\
\text { deal with disturbance }\end{array}$ \\
\hline \multirow{3}{*}{$\begin{array}{l}\text { Community involvement \& } \\
\text { inclusion of local knowledge }\end{array}$} & $\begin{array}{l}\text { Shared rights and responsibilities for } \\
\text { resource management }\end{array}$ \\
\hline & $\begin{array}{l}\text { Community engagement, ownership, } \\
\text { participation }\end{array}$ \\
\hline & $\begin{array}{l}\text { Combined scientific and indigenous/local } \\
\text { knowledge }\end{array}$ \\
\hline \multirow{3}{*}{ Preparedness and planning } & $\begin{array}{l}\text { Timely information, plans embedded in } \\
\text { institutions }\end{array}$ \\
\hline & Redundancy and planning for failure \\
\hline & Investment in agency and adaptive capacity \\
\hline \multirow{3}{*}{ High degree of equity } & Account for equity and justice \\
\hline & $\begin{array}{l}\text { Equitable economy and distribution of assets } \\
\text { and wealth }\end{array}$ \\
\hline & $\begin{array}{l}\text { 'Hard' or technical adaptations may fail to } \\
\text { address equity }\end{array}$ \\
\hline \multirow{2}{*}{$\begin{array}{l}\text { Social capital, values and } \\
\text { structures }\end{array}$} & Trust, norms and values \\
\hline & Address multiple values and interests \\
\hline \multirow{2}{*}{ Learning } & $\begin{array}{l}\text { Essential to cooperate, learn and apply } \\
\text { lessons }\end{array}$ \\
\hline & $\begin{array}{l}\text { Iterative programme processes or } \\
\text { organisational learning }\end{array}$ \\
\hline \multirow{3}{*}{$\begin{array}{l}\text { Adoption of a cross-scalar } \\
\text { perspective }\end{array}$} & Transcend the local scale \\
\hline & Engage with short and long time horizons \\
\hline & $\begin{array}{l}\text { Networks across regions, links to community } \\
\text { structures }\end{array}$ \\
\hline
\end{tabular}

Community-based adaptation assessments conducted in Timor-Leste and Solomon Islands were selected as case studies. These particular studies offer an unusually comprehensive approach to CBA assessment in terms of the breadth and detail of ex-ante analyses of adaptations from a social, economic and ecological perspective (Ensor, 2014). Their application was typical of many in terms of the development context, with both countries being characterised by substantial populations living in extreme poverty (e.g. in Timor-Leste 34.9\% of the population lives on less than USD1.25 per day; WorldBank, 2015). Both 
nations have also recently experienced civil unrest resulting in fragmented development efforts. This, together with critically limited state services, has led to both countries having a heavy reliance on external interventions provided by national and international NGOs. Together with weak formal governance systems, traditional practices influence access to and the use of natural resources that underpin the vast majority of rural livelihoods (Govan et al., 2013a; Mills et al., 2013).

All three case studies can be described as aquatic agricultural systems (AAS), that is: "systems in which the annual production dynamics of freshwater and/or saline or brackish coastal systems contribute significantly to total household income" (CGIAR, 2012). Such systems typically deliver a wide range of ecosystem services including food, water, firewood and charcoal (provisioning services), and pollination, pest control, flood control and water quality (regulating services) (Estrada-Carmona et al., in prep), as well as important habitat for a wide range of threatened species (e.g. BirdLife International, 2015). Production fluctuates naturally (Castine et al., 2013) and a range of activities are practiced, including cropping, livestock, capture fisheries, aquaculture, and harvesting of various wild plant and animal species. The fishing and farming livelihoods operating within these complex social-ecological systems rely on the sustainable management of aquatic and terrestrial natural capital and the ecosystem services they provide. Supporting an estimated 700 million poor and vulnerable people globally, and displaying a paradoxically high potential productivity in the face of persistent and extreme poverty and food insecurity (Madzudzo et al., 2013), added with challenging governance issues (Ratner et al., 2013; Ensor et al., 2015), these complex and spatiotemporally dynamic agro-ecological systems require a multi-disciplinary research approach to community development. The coastal locations of the Timor-Leste and Solomon Islands case studies also means long-term increases in sea level and ocean acidification, as well as shortterm changes in seasonal temperature and rainfall patterns, and an increased frequency of extreme climate events, will exacerbate existing development challenges.

The CBA assessment phase in Timor-Leste and Solomon Islands was undertaken by a multidisciplinary project team including two authors of this paper, during the period August 2012 to June 2013 (Park et al., 2012). The studies drew on findings from previous social and ecological assessments of community livelihoods and the socio-economic context (Mills et al., 2013). The assessments were conducted with farming and fishing communities across the island of Atauro, and around the coastal sub-district of Batugade, in Timor-Leste. Similar participatory tools were used to conduct assessments with a community of practice (focusing on aquaculture ponds as an adaptation technology) in Malaita Island, Solomon Islands. The CBA assessments worked through a stakeholder participatory process to consider the likely impacts of climate change on livelihoods, identify potential adaptation options, evaluate a small number of adaptations in terms of the potential or likely social, economic and environmental consequences, and synthesise the findings to consider an implementation strategy. As such, the role of this assessment phase in the CBA was to define the nature of the problem being addressed and thereby 
circumscribe the development intervention. Drawing on first-hand experience of conducting these assessments in Timor Leste and Solomon Islands the following analysis provides insight into the potential of the seven assessment activities to build key attributes of resilience as identified by Bahadur et al. (2013). As such, the analytical approach offers practitioners a practical means of translating key aspects of resilience theory into the design, implementation and evaluation of CBA activities.

Summary details for each CBA assessment activity are shown in Table 2, together with the key research questions being addressed. Different combinations of activities were undertaken in the case study locations to reflect the specific context, existing documented knowledge and past studies. The activities were undertaken in participation with farmers and fishers from the target communities, local NGOs and district/provincial and national government representatives.

Table 2. Summary of case study CBA activities and key research questions.

\begin{tabular}{|c|c|}
\hline Tool & Method \\
\hline \multicolumn{2}{|l|}{ Climate analysis } \\
\hline $\begin{array}{l}\text { Key question: What are the } \\
\text { likely impacts of a change in } \\
\text { future climate on fishers' and } \\
\text { farmers' livelihood activities? }\end{array}$ & $\begin{array}{l}\text { Statistical analysis and statistical modelling* undertaken to } \\
\text { identify trends in observed mean monthly temperature and } \\
\text { rainfall data }[1,2,3]\end{array}$ \\
\hline \multicolumn{2}{|l|}{$\begin{array}{l}\text { Impacts and adaptation } \\
\text { workshop }\end{array}$} \\
\hline $\begin{array}{l}\text { Key question: Given projected } \\
\text { changes in climate which } \\
\text { adaptations will help realise a } \\
\text { shared vision of the future? }\end{array}$ & $\begin{array}{l}\text { Climate-sensitive livelihood activities identified and impacts } \\
\text { considered given observed past trends and published } \\
\text { projections of future climate }[1,2,3] \text {; Participation: female } \\
n=16 \text {, male } n=66 \text {. Adaptations identified } 1,2 \text { (specific to } \\
\text { aquaculture [3]); Youths in the community drew their vision } \\
\text { of a desirable future [1,2] Participation: female } n=7 \text {, male } n=2 \text {. }\end{array}$ \\
\hline \multicolumn{2}{|l|}{$\begin{array}{l}\text { Decision tree and partial } \\
\text { cost-benefit analysis }\end{array}$} \\
\hline $\begin{array}{l}\text { Key question: How can } \\
\text { adaptations be designed and } \\
\text { what are the relative partial } \\
\text { costs and benefits of each } \\
\text { design? }\end{array}$ & $\begin{array}{l}\text { Key decisions and design steps identified for a selection of } \\
\text { adaptation responses (e.g. a specific method of fishing), } \\
\text { together with the full permutation of potential pathways for } \\
\text { developing and implementing them [1]; Partial costs and } \\
\text { benefits estimated for each adaptation design [1]. } \\
\text { Participation: female } n=7 \text {, male } n=28 \text {. }\end{array}$ \\
\hline \multicolumn{2}{|l|}{ Social network analysis } \\
\hline $\begin{array}{l}\text { Key question: Who is } \\
\text { necessary to facilitate } \\
\text { effective planning, } \\
\text { implementation, and on-going } \\
\text { application of adaptation } \\
\text { options? }\end{array}$ & $\begin{array}{l}\text { Baseline social networks produced by identifying key actors } \\
\text { influencing the capacity to farm or fish }[1,2,3] \text {; existing links } \\
\text { between actors identified in terms of flows of information, } \\
\text { physical support (e.g. equipment), financial support (cash } \\
\text { and loans), and services (e.g. training, marketing), as well as } \\
\text { power relations }[1,2,3] \text {; participation: female } n=13 \text {, male } n=56 \text {. } \\
\text { Additional actors necessary for enabling effective planning, } \\
\text { implementing and iteratively managing an adaptation }[1,2] \\
\text { (or aquaculture [3]) identified, and the nature of their } \\
\text { linkages characterized; participation: female } n=11 \text {, male } n=31 \text {. }\end{array}$ \\
\hline $\begin{array}{l}\text { Governance capacity } \\
\text { analyses (semi-structured } \\
\text { interviews \& survey of } \\
\text { governance and }\end{array}$ & \\
\hline
\end{tabular}




\begin{tabular}{|c|c|}
\hline institutions) & \\
\hline $\begin{array}{l}\text { Key question: What is the } \\
\text { present capacity of } \\
\text { Government to build resilient } \\
\text { fishing and farming } \\
\text { communities and what } \\
\text { further enabling } \\
\text { opportunities can be } \\
\text { explored? } \\
\text { What are community } \\
\text { perspectives of the capacity of } \\
\text { national level Ministries and } \\
\text { NGOs in building resilience in } \\
\text { rural livelihoods? }\end{array}$ & $\begin{array}{l}\text { Information on the formal and traditional governance and } \\
\text { institutional environment collated from semi-structured } \\
\text { interviews with national, regional and community level } \\
\text { stakeholders using a snowball sampling strategy, secondary } \\
\text { literature, network analyses and community survey [1,2,3]; } \\
\text { data synthesised using the CORE and modified PROFOR }{ }^{1} \\
\text { frameworks*. } \\
\text { Governance and institutions survey containing ten open- } \\
\text { ended and multiple choice questions developed with, and } \\
\text { conducted by, a local NGO [1.2]. Participation } n=150 \text { fishers } \\
\text { and farmers; Data analysed to produce descriptive statistics*. }\end{array}$ \\
\hline \multicolumn{2}{|l|}{ Landscape Function Analysis } \\
\hline $\begin{array}{l}\text { Key question: Which land- } \\
\text { management adaptations can } \\
\text { be used to increase the } \\
\text { ecological function of } \\
\text { agricultural soils and } \\
\text { resilience of farming systems? }\end{array}$ & $\begin{array}{l}\text { Home gardens were categorised according to the extent of } \\
\text { their management intensification and modification [1,2]; } \\
\text { Multiple replicates of } 50 \mathrm{~m} \text { transects were established } \\
\text { through the home gardens and soil ecological function } \\
\text { assessed along them using Landscape Function Analysis } \\
(\mathrm{LFA})^{2}[1,2] ; \text { LFA results were used to estimate aspects of soil } \\
\text { function critical to production (i.e. soil structure stability, } \\
\text { nutrient cycling and water infiltration/run-off)*; adaptations } \\
\text { were considered in terms of their potential impact on current } \\
\text { soil function*. }\end{array}$ \\
\hline \multicolumn{2}{|l|}{ Ecosystem services mapping } \\
\hline $\begin{array}{l}\text { Key question: What and } \\
\text { where are the most important } \\
\text { natural assets (and associated } \\
\text { ecosystem services) } \\
\text { underpinning livelihoods? } \\
\text { Where might the introduction } \\
\text { of additional aquaculture } \\
\text { ponds lead to land and } \\
\text { resource use } \\
\text { coincidence/conflict? }\end{array}$ & $\begin{array}{l}\text { Provincial and national government stakeholders } \\
\text { superimposed on printed maps the following elements of the } \\
\text { land and seascape considered important for supporting } \\
\text { livelihoods: fisheries, agricultural resources, recreation and } \\
\text { tourism sites, natural resources (e.g. native vegetation), and } \\
\text { aquaculture (both current and aspirational) [3]; participation: } \\
\text { female } n=0 \text {, male } n=3 \text {. Mapped elements were digitised using } \\
\text { Google earth and secondary information (e.g. reports, papers, } \\
\text { media, relevant hyperlinks) linked to each element to } \\
\text { produce an open-access, spatial database of natural resource } \\
\text { use*. Spatial coincidence between existing land uses/natural } \\
\text { resources and potential location of future land-based } \\
\text { aquaculture (as identified by national government } \\
\text { stakeholders) were assessed in terms of water use, land } \\
\text { availability, and potential production trade-offs*. }\end{array}$ \\
\hline \multicolumn{2}{|l|}{ Implementation planning } \\
\hline $\begin{array}{l}\text { Key question: How useful are } \\
\text { the CBA outputs for planning } \\
\text { how to adapt? } \\
\text { What adaptations should be } \\
\text { implemented, and when? }\end{array}$ & $\begin{array}{l}\text { Results from social, economic and environmental evaluations } \\
\text { of adaptations were considered by the communities, in terms } \\
\text { of their credibility, salience and legitimacy }{ }^{3} \text { for adapting to } \\
\text { climate change [1,2,3]; participation: female } n=9 \text {, male } n=72 \text {. } \\
\text { Discussion facilitated on thresholds (tipping points) likely to } \\
\text { prompt implementation of adaptations }[1,2] \text {; communities } \\
\text { identified the top three priority actions they needed to take } \\
\text { to catalyse their adaptation action plan [1,2]; participation: } \\
\text { female } n=6 \text {, male } n=41 . .\end{array}$ \\
\hline
\end{tabular}

The case studies are indicated: [1] = Atauro, Timor-Leste; [2] = Batugade, Timor-Leste; [3] $=$ Malaita, Solomon Islands. Activities without stakeholder participation are indicated $(*)$.

${ }^{1}$ Govan et al. (2013b)

2 Tongway and Hindley (2004)

${ }^{3}$ Cash et al. (2003) 


\section{Results}

The following describes the extent to which each of the resilience characteristics identified by Bahadur et al., (2013) were addressed during the case study CBA activities. Table 3 provides a visual summary of the results in terms of the contribution of each activity to the ten characteristics (in which we take 'contribution' to mean the extent to which each activity draws a characteristic into the CBA process). The activity contributions are assessed as low, medium or high. This grading is based on the analysis provided in the following paragraphs, and seeks to offer an indicative assessment of the individual and collective utility of the activities from a resilience-building perspective.

\section{High Diversity (social and ecological)}

Important aspects of diversity are only partially captured in the process and outcomes of the CBA assessment. For example, a disproportionally high ratio of males to females, and only a small number of youths (the latter being limited to the visioning activity in Atauro) participated in the three case studies. Nonetheless, the activities produced a range of perspectives, experiences and thinking that was at times rigorously debated amongst the participants. This was reflected in an array of perspectives on the likely impact of climate change and options for adapting, with a total of 70 potential impacts and 100 technical and economic adaptation options identified by the communities of Atauro and Batugade, Timor-Leste. Despite predominantly male participation, social network analysis revealed a diversity of networks, stakeholders and relations that provide access to resources and are available to support adaptive actions. The governance analysis incorporated a range of perspectives on the efficacy of the national level ministries and NGOs to support fishing and farming activities. Ecological diversity was represented in a number of the CBA assessment activities. The ecosystem services mapping undertaken in the Solomon Islands provided an understanding of the diversity and complexity of the spatial distribution of natural assets, and the various users that access or impact them. Similarly, the landscape function analysis undertaken in Atauro, Timor-Leste provided an understanding of the structural and compositional diversity of landuse, and in particular the importance of diversity (e.g. of crop species) in terms of maintaining ecological function (Letourneau et al., 2011) and supplying a range of nutrients leading to increased dietary diversity (Toledo and Burlingame, 2006). This resulted in a number of management recommendations being proposed aimed at improving soil condition and nurturing ecological functions and ecosystem services necessary for crop production for food security and income generation.

\section{Effective governance and institutions}

The impact and adaptation assessment workshops, decision tree and cost benefit analyses, and the implementation planning processes were able to reflect local norms via community participation. In so doing, these participatory approaches hold the potential to embed adaptation planning in local institutions, which in turn are rooted in and responsive to changing local realities (Agrawal, 2010). Social network analysis revealed relational ties that enable information and resource flows and decision making in governance networks. It also included an explicit focus on power relations and explored community perspectives on the 
implications of imbalances of power on their access to resources and capacity to adapt. The governance analysis examined key actors in governance structures and institutions and the influence of their capacity and effectiveness on service delivery and hence livelihoods and vulnerability at the local level. The net effect of the social network and governance analysis was a detailed understanding of the formal and informal governance context in which the stakeholders are seeking to adapt. Importantly this covered the national to local scales and included a community perspective on governance gaps, legitimacy, accountability and representation, the relative significance of power relations, and the myriad rules, regulations and decision making processes on their ability to adapt. Community participants reflected upon this information during the implementation planning activity to consider what institutions needed to be engaged in their social networks to facilitate a specific adaptation being implemented and sustainably used. This fed into discussion whereby the community agreed upon the top three priority actions for catalysing their adaptation action plan.

\section{Acceptance of uncertainty and change}

Climate analysis was used to identify trends in historical climate data and establish current model-based projections for future climate. The results were presented to community members, who shared their own personal experiences of variability and shifts in weather patterns. This led towards an acceptance and understanding of climate change in order to galvanise discussions around actions. During the impact and adaptation assessment workshop, emphasis was placed on uncertainty in the rate and magnitude of future climate change. The researchers worked with communities to try to determine how uncertain climate change and future resource availability could impact upon the fishing and farming livelihoods. This, in turn, was used as a trigger to identify a wide range of adaptation actions, while recognising considerable uncertainty in the suitability, costs and benefits of different actions. Decision tree analysis explicitly explored climate change and other risks and uncertainties for different adaptation options, identified by the fishers and expressed as the probability of outcome occurrence, and feeding into cost benefit analysis. Landscape Function Analysis and ecosystem services mapping was used to provide greater clarity (i.e. reduced uncertainty) in relation to the likely outcomes resulting from adaptation options, with results illustrating how the management of home gardens can be used to increase productive function in Timor-Leste. As used in Solomon Islands, the ecosystem services analysis explored the potential for competing demands to result in the broader landscape from land and resourceuse change associated with land-based aquaculture ponds. In each case, the participatory processes supported acceptance of the need to deal with uncertainty and change.

\section{Non-equilibrium system dynamics}

The identification of long-term and likely future trends through the climate analysis process drew attention to the non-equilibrium dynamics of the climate system. However, the subsequent discussions with participants at the workshop gave little attention to more immediate impacts of multiple, interacting drivers of change on the resilience of fishing and farming (e.g. clearing of native 
vegetation, burning of crop residues, over-fishing of near-shore coral reefs), or on the social-ecological system more broadly. Indeed, of the array of adaptation options identified by the communities in the three CBAs, none were likely to result in fundamental change (i.e. transformation of the system). The predominant focus on climate did not incentivise strategies for dealing with the relationship between multiple social and ecological elements in the system (cf. Folke, 2006), the consequent high degree of uncertainty, and the transient nature of systems that are not near equilibrium. As a result, the discussion of climate change, impacts on livelihoods, and the identification of feasible adaptation actions was largely ineffective in exploring the dynamic and complex interrelationship between the community and their environment. Landscape Function and ecosystem services analyses accounted for non-equilibrium dynamics by, for example, exploring how to maintain productive function in the face of change through identification of the structural components in the landscape, or how changes in land use will impact on ecosystem services at the landscape scale.

\section{Community involvement and inclusion of local knowledge}

Community involvement and the inclusion of local knowledge was a central characteristic of the vast majority of tools and methods used in the three case studies. For example, consideration of past climate through observations of temperature and rainfall and subsequent statistical analysis, was reviewed by the community and triangulated with their experiences of weather patterns occurring over their lifetimes. Equally, the community involvement in identifying potential impacts of climate change on livelihoods, potentially suitable adaptation actions, and the highest priority actions requiring immediate research, were all essential and explicit components of the impact and adaptation assessment workshops. These results informed ex-ante analyses (i.e. decision tree, cost benefit, landscape function and ecosystem service analyses) that drew to varying degrees on local knowledge. Similarly the social network and governance analyses relied on securing community perceptions of institutions, actors and networks of relationships. Each of these processes enabled communities to engage with and adopt a degree of ownership over the adaptation planning process, building knowledge and understanding among both the researchers and community members.

\section{Preparedness and planning}

The suite of tools used in the CBA process was explicitly aimed at enhancing preparedness through planning adaptation actions and pathways for their implementation and sustainable management. For example, by providing a snapshot of possible climate futures, climate analysis was used to inform discussions on livelihood impacts and potential adaptation actions. Similarly, the ex-ante analyses supported decision-making and planning regarding the most effective adaptation actions. Preparing and planning for disturbances was clearly the explicit outcome sought from the final adaptation planning activity. Though less explicit, the decision tree analysis is also notable in enhancing community preparedness. By exploring a broad range of gear and techniques available for fishing coastal waters, community members produced a realistic plan for adapting fishing under different potential climate futures. The plan identified key 
decisions and design steps that need to be taken for the full permutation of fishing methods, and the decision pathways that could be taken. Understanding the relative costs and benefits of each fishing method and pathway enabled the fishers to determine the relative merits and substitutability of different methods in addressing the adaptation challenge. As such, failure planning was embedded in the design of this CBA tool. The analysis of formal and informal governance (through social network analysis and governance analyses) provided the foundations for understanding how planning, of say the delivery of timely weather forecasts or crop management recommendations, could be integrated into existing institutional processes. However, this was in effect only the first of many steps required to realise pathways to a more effective enabling environment for the communities.

\section{High degree of equity}

Whilst the general participatory approach adopted in the CBA case studies has potential to contribute to realising resilience through engaging stakeholders in a manner that promotes a high degree of equity in voicing opinions and soliciting input, the limited participation of marginalised groups (e.g. women and children) meant that this was not fully realised in the three case studies. Difficulty in attracting marginal groups to participate in the CBA activities, and differential access to resources identified in the social network analysis, both suggest substantial economic and social inequities exist in the case study communities. The strongest potential contribution for building equity in the community in the future lies in social network and governance analysis. None of these tools explicitly drew out equity considerations, but the detailed analysis explored representation and accountability in formal and informal institutions, revealing, for example, the prominent role of tradition and lineage in determining power and representation in informal decision making institutions. Equity was not considered in the other CBA tools used.

\section{Social capital, values, and structures}

Community involvement in all activities initiated learning and improved community capacity to engage in systematic debate on issues of change and adaptation. This can be seen as a step towards building a network of individuals at the community level with shared norms and increased trust in relation to climate change adaptation. Social network analysis was the primary activity in exploring existing social support, social embeddedness, organisational linkages and leadership within communities. This tool can increase community understanding of bridging and bonding capital while revealing the structure of governance; as noted by Schiffer and Hauck (2010) "researchers, facilitators, and implementers ... understand the interplay of complex formal and informal networks, power relations, and actors' goals". The potential of this activity was evident in both the geographic communities in Timor-Leste, as well as the community of practice engaged in Solomon Islands. In a similar sense, the ecosystem services mapping tool enabled stakeholders to understand their social embeddedness and linkages as mediated through the use of natural resources. This activity explicitly highlighted the goals, values and competing interests of different actors at community and landscape scales. By revealing the inherent heterogeneity amongst and between communities, this tool provided a 
forum for the participating stakeholders to discuss potential conflicts arising from adaptations that alter land use and result in trade-offs in accessing (and impacting) the ecosystem services underpinning rural livelihoods.

\section{Learning}

The sequence of activities undertaken in all three case studies was designed to provide multiple opportunities to share, generate and understand new knowledge (ISET, 2010). It was also designed to highlight the utility of iterative management of climate change adaptation and promote the learning and skills to enable an ongoing adaptive process. During the final implementation planning workshop, the opportunity to reflect back on the usefulness of the information produced was a key step in this cycle of learning. In addition to this sequence of activities, individual activities also contributed to learning. For example, the climate data introduced and reflected on at the impact and adaptation workshop provided a platform for community members to engage with and apply information on climate change to their local contexts. The process of translating this information into potential impacts and adaptations at the local level enabled 'situated learning' among community members, who together arrived at a shared understanding that both reflects and shapes their context, culture and set of practices (Lave and Wenger, 1991; Reed et al., 2010). The same holds for the evaluation activities (Decision Tree and Cost Benefit, Social Network and Ecosystem Service Mapping), in each case (albeit in proportion to the degree of participation). However, the statistical analysis of the historic climate data and the analysis of Landscape Function were largely undertaken by the research team in isolation, despite considerable efforts to engage local stakeholders. The lack of incentives and/or opportunity for these stakeholders to become involved resulted in a missed opportunity for awareness raising, capacity building and increased understanding amongst the in-country government, NGO and research communities. Such organisational learning was generally weak in all the assessments activities.

\section{Adoption of a cross-scalar perspective}

Exploration of a cross-scalar perspective is most evident in the social sphere through the use of governance and social network analysis tools. Social network analysis was used to illustrate the connectivity between the community and other stakeholders, drawing attention to the relationships that support (or undermine) the capacity to adapt at the local level. The participatory processes were undertaken independently with community and local government actors, allowing influential relationships, actor attributes specifically relating to power and influence, and the extent of their support to be openly discussed by each actor. The technique was also used to identify where new relationships may need to be built in order to achieve particular adaptation strategies, and was supported by the governance analysis in which information on the formal and informal governance environment was collected from local, regional and national stakeholders, acknowledging the need for vertical integration. A crossscale perspective was embedded in environmental and ecosystem analysis of the management practices used in home gardens in Atauro and Batugade, on landscape function (via rapid assessments of soil condition) and the consequences of land-use changes on livelihood activities and ecosystem-service 
functioning (at an island-wide scale in Malaita). These activities were both important in highlighting the need to take into account potential trade-offs and synergies across multiple scales that may result from community-scale adaptations.

\section{Discussion}

It is evident from this comparison of the CBA assessment activities undertaken in the in-situ case studies, against the Bahadur et al., (2013) characteristics, that there is much potential for CBA to contribute to the resilience of communities. As summarised in Table 3, the use of the tools examined here provide a firm basis for exploring - and subsequently acting on - each of the ten characteristics of resilience. This strength derives principally from the correlation between the focus of the tools and many of the characteristics; on the evidence here, resilience and CBA have much in common.

\section{CBA methods: equity, flexibility and learning}

Social network analysis and governance analysis fulfil an essential role by developing an understanding of the locus of power and authority in relation to potential adaptation actions, and providing insight into the complexity of overlapping formal and informal institutions. Both are pre-requisites for planning adaptation actions that are feasible, effective and equitable (Agrawal, 2010; Dodman and Mitlin, 2011). Yet, there is a need for a more direct analysis of procedural and distributional justice in governance (Fainstein, 2015; Nelson et al. 2007). To reveal this requires a shift in the focus of the assessment methods, and the use of carefully disaggregated community participation in those methods. However, representation and social differentiation emerged as key methodological challenges in the case studies, undermining the contribution of the assessments to the achievement of equitable outcomes, and failing to explore whether adaptation needs to contribute to a transformation in social and political relations.

Social network and governance analysis revealed those actors and institutions with the mandate and capacity to support the development and implementation of adaptation strategies, the relationships on which the community could call or would need to strengthen, and the potential of current governance arrangements to support adaptation planning. Social network analysis has particular significance, helping to identify any potentially dysfunctional cross-scale relationships that could undermine the emergence of equitable adaptation (Pauwelussen, 2016; Ingalls and Stedman, 2016; Yates, 2012). Not only is this contextual information needed to build towards broad-based adaptation institutions, it also highlights the need for CBA activities to address power dynamics that can lead to iniquitous trade-offs. In turn, this can underpin analysis of adaptive capacity and how governance and institutions structure opportunities for communities to respond to and shape change (Agrawal, 2010; Armitage et al., 2011; Eakin and Lemos, 2010; Gupta et al., 2010; Pradhan et al., 2012). 
A key strength of CBA tools lies in their participatory methodologies, embedding local knowledge, voices and norms into the adaptation planning process and embedding diversity into many of the assessment processes. But the ability to capture diverse views in participatory methods depends on skilled facilitation to ensure all perspectives are represented, and in particular to ensure intracommunity power dynamics do not supress the views of particular groups even when represented (Forsyth, 2013; Kanji and Tan, 2008). In the three case studies explored here, gender equality was poor (for example, in the lack of women's involvement in the semi-structured governance interviews, reflecting the preponderance of men employed in government positions in the fishing and farming sectors). Ensuring that diverse opinions and values (within and across scales) are represented and respected in the assessment methods is by no means straightforward, but is necessary to ensure the knowledge, values and perceptions of communities are integrated into planning; to mitigate the potential for elite capture of adaptation resources; and to avoid perpetuating inequitable (albeit resilient) development outcomes (Ensor, 2014; Forsyth, 2013; Granderson, 2014; Walker et al., 2014; Pauwelussen, 2016; Ingalls and Stedman, 2016; Yates, 2014).

The absence of an overarching focus on resilience in the CBA methods also means there is no attention to the key governance attributes of flexibility or openness to experimentation and learning (Folke et al., 2005). While participatory methods provide learning opportunities for those involved, the resilience perspective emphasises learning as a core component of adaptation. This draws particular attention to governance analysis, where an assessment could have been made of the capacity for learning. Learning enables choices to be made under uncertainty, informed by past experience and with the expectation of continuously reviewing and revising actions. At a deeper level, the goals and procedures of decision-making may also be brought into question, which may prove particularly significant in the face of unprecedented change or to take account of marginalised interests and values of stakeholders at different scales (Armitage, 2008). The CBA assessment process was largely effective in enhancing preparedness through planning adaptation actions and the pathways required for their implementation. Yet without exploring flexibility and learning in governance and institutions, it is unclear how incremental changes (anticipated in the decision tree analysis) can be managed, and whether unanticipated future changes can be mitigated. Consideration of power and equity are equally significant: who wins and loses from flexibility in the norms and processes of governance? Whose knowledge is preferred in learning processes, and who gets to learn (Ingalls and Stedman, 2016)? Are governance processes and institutions are locked into 'command and control' norms and practices, thus prohibiting responsiveness to changing social and environmental conditions (Brunner and Lynch, 2010; Folke, 2003)?

To capitalise on or ferment flexible, learning institutions CBA assessments must, first, reveal the extent to which these attributes are present in formal and informal settings and the degree to which individuals are empowered and prepared to make changes. At the community scale, the wider psychology literature suggests that there is also a need to engage with overlooked questions 
of optimism, leadership, self-esteem and people's relationship to place in understanding agency and capacity for self-organisation in the face of emerging shocks and stressors (Berkes and Ross, 2013; Brown and Westaway, 2011; Miles, 2015; Apgar et al. 2015). Second, assessments need to explore and exploit opportunities to build cross-scale relationships in support of learning and adaptation decision-making, rooted in and responding to an understanding of how pre-existing social and cultural relations influence access to and control over institutions (Cote and Nightingale, 2012; Dagdeviren et al. 2015; Sjostedt, 2015). In the case studies, community involvement did not extend to building relationships with stakeholders - despite the aim to share, generate and understand new knowledge through the methods used. This shortcoming was compounded by the framing of adaptation as a linear process, and a consequent failure to incentivise strategies for dealing with on-going uncertainty, multiple drivers of change, or competing perceptions of value, or to build relationships between the community and other sources of knowledge. To embed cross-scale learning into the local management of climate change requires commitment from external organisations (which was weak and resulted in the limited participation of representatives) and CBA methods that are embedded in processes that incrementally engage the community and external stakeholders. These joint activities can build trust and be centred on embedding learning (and power sharing) in new or existing institutions (see, for example, Broto et al., 2015). Yet the short duration of many CBA projects does not necessarily lend itself to building effective working relationships, and highlights the need for CBA to be integrated into longer-term commitments to understanding social dynamics and building capacity (cf. Eade, 2010).

\section{Resilience characteristics}

A major contribution of the characteristics lies in the observation that no single CBA activity can address the breadth of issues captured by resilience. Resilience is multifaceted and, as a consequence, applying resilience thinking demands multiple methods that cut across disciplines and skill sets. The overall coherence of the CBA assessment process demands a suite of integrated tools and activities that together explore resilience and are tailored to the target community or community of practice. In the case study, Landscape Function Analysis and Ecosystem Service Mapping were found to be important tools for addressing a majority (eight) of the characteristics, offering insights into ecological system components that were not visible through the other tools. To achieve these outcomes demanded particular, specialist skills that are often overlooked in development and CBA (Ensor, 2014), underlining the value of framing resilience in terms of diverse characteristics. The benefits, in this case, were manifold, identifying the interconnectedness of social and ecological components across scales and within a complex systems perspective, and recognising the interrelated nature of social and ecological diversity, the diversity of people and uses of the natural environment, and the importance of biodiversity in maintaining multiple ecosystem functions and services in a complex system (Berkes, 2007). Without this perspective the ability of a CBA to address socialecological resilience will necessarily be significantly weaker, lacking an appreciation of, for example, the significance of potential shifts in ecological 
diversity and productivity, and adaptation trade-offs that may arise between land-use types and across scales.

Yet the question of the selection of methods by those undertaking CBA assessments is intimately tied to the perception of what adaptation is for. What are NGOs trying to achieve? The case studies examined here offer an example of livelihoods assessment that explicitly recognises the importance of changes in ecosystem structure and function, and focuses attention on networks of support for adaptation actions. This suggests an underlying focus on addressing climate change impacts, but with limited ambition in terms of engendering equitable and flexible learning institutions, and addressing the underlying social and political context. But if NGOs are to appreciate and work towards overcoming structural and historically-situated barriers to adaptation (and in so doing support the resilience of those who are currently marginalised in society) then a sharper political edge is needed in the CBA assessment methods and the analysis that results (Bassett and Fogelman, 2013; Ensor et al., 2015; Pelling, 2011).

Bahadur et al.'s (2013) overt attention to equity as a separate characteristic of resilience has particular significance here, as it brings the potential to shift the focus of CBA beyond resource management and livelihoods, and onto a more explicit engagement with the relationship between structure and agency (Dodman and Mitlin, 2011; Pelling et al., 2014) and the cultural and historical roots of social difference (Cote and Nightingale, 2012; Sjostedt, 2015). Adaptation actions may then include (for example) support for the empowerment of marginalised groups in different institutional settings. However, to do so requires reading a great deal of meaning into a single characteristic focused on taking account of "issues of justice and equity" in the distribution of wealth and assets, between generations and via attention to "soft" social systems (Bahadur et al. 2013: 7). Recent trends in the literature reveal at least four important themes: (i) the uneven power relations and risk perception within communities (Ensor, 2014; Forsyth, 2013; Granderson, 2014; Walker et al., 2014); (ii) the scalar politics of vulnerability and resilience (Pauwelussen, 2016; Ingalls and Stedman, 2016; Yates, 2012); (iii) the inadequacy of institutional design in addressing historically and culturally embedded relations of power (Cote and Nightingale, 2012; Dagdeviren et al. 2015; Sjostedt, 2015); and (iv) the significance of structure and knowledge in determining "who is getting what" from resilience (Biermann, 2015; Dagdeviren et al. 2015; Fainstein, 2015; Ingalls and Stedman, 2016; MacKinnon and Derickson, 2013).

Some of these insights are touched on within those characteristics concerned with the conditions under which resilience can emerge and be sustained: the focus on equity, the need for legitimate institutions, the integration of local knowledge, and social capital's concern with shared values, for example. Yet this (partial) diffusion of the four themes across the characteristics adds to the sense that resilience "obfuscates" power and politics (Fainstein, 2015), undermines the potential for deliberate transformation (Davies 2015; Dodman and Mitlin, 2011; Fook, 2015) and risks reinforcing existing inequalities (Robinson and Carson, 2015). Addressing the highly context specific nature of power and social difference demands a situated practice of resilience, in which the methods 
through which resilience is applied contain an overt focus on the four themes identified above. As such, these insights are perhaps best seen as framing and containing, rather than adding to, Bahadur's characteristics.

\section{Conclusions}

This paper has set out to answer whether community-based adaptation (CBA) can build resilience. Based on the examination of three case studies, the answer is a cautious 'yes'. While limitations have been identified, the methods employed in the case studies shed light onto how CBA practice can lead to improved resilience. However, we emphasise that we are not proposing a prescription, but rather helping to identify the contents of a toolbox for supporting resilience through CBA. Within this, we emphasize the need to be responsive to the historically embedded social, cultural and political context, and for CBA practitioners to engage with changes in the ecological, as well as the social, system. Resilience is multifaceted, and as such supporting resilience through CBA will demand multiple staff with different skills. Case study analysis proved a useful means to both identify ways in which resilience was likely enhanced, and offered a critique upon which additional modifications and activities can be developed that may further realise the building of resilience. As such, using the characteristics as an analytical framework offers support to practitioners looking to develop, implement or evaluate CBA assessment activities

CBA has inherent strengths in relation to resilience. In particular, the focus on local decision making and bridging or synthesising scientific and local knowledge provides a strong basis for resilience, seen in the contribution of the 'impact and adaptation' and 'implementation planning' workshops to several of the characteristics. However, the mix of methods used in CBAs is also crucial: attention to landscape function and ecosystem services in the case studies is atypical, but was demonstrated to be essential for understanding socialecological resilience. It is also important to recognise that the methods analysed here were carried out as assessments: they provide the blueprint for subsequent CBA actions. Their examination is valuable as they reveal the intention and ambition of CBA, providing insight into the extent that adaptation interventions can contribute to resilience. Yet much will also depend on the manner in which plans are translated into actions. The mechanisms and processes through which development proceeds will also play a role in determining whether resilience is equitably realised by communities.

Simultaneous consideration of all ten resilience characteristics challenges CBA practitioners to move beyond viewing adaptation in terms of communities and climate impacts that are isolated from their wider context. On the evidence here, characteristics need to be understood as cross-cutting, receiving due consideration in all of the methods used if adaptation planning is to proceed from a resilience perspective. While the CBA methods adopted in the case studies collectively address all the characteristics of resilience, the absence of a particular characteristic in any one of the methods can radically undermine the contribution that CBA can make to resilience. In particular, the failure to embed equity and learning highlights the need for practitioners to consciously attend to 
the complexity inherent in social-ecological systems and the conditions under which resilience can emerge and be sustained.

Finally, it remains for practitioners to engage with critiques of resilience and acknowledge the potential for sustaining and reinforcing existing relations of power and resource access. Themes identified within the recent literature direct questions towards the roots of power and inequality, and the consequences for procedural and distributional justice. We suggest that addressing the highly context specific nature of power and social difference demands a situated practice of resilience, in which the methods through which resilience is applied contain an overt focus on (i) uneven relations and power and risk perception within communities, (ii) the scalar politics of vulnerability and resilience, (iii) the inadequacy of institutional design for addressing historically and culturally embedded relations of power, and (iv) the significance of structure and knowledge in determining "who is getting what" from resilience. This suggests that practitioners need to adopt a much more critical engagement with resilience in CBA than the much-repeated goal of 'increasing resilience' has suggested to date. Rather, adopting a resilience perspective means recognising that, in some circumstances, transformation may also be necessary. With this, resilience can become a progressive framing for CBA.

\section{Acknowledgements}

Thanks go to community members in Timor Leste and Solomon Islands who provided inspiration during the case studies undertaken by Park et al., (2012), co-funded by Asian Development Bank (ADB), Global Environment Fund (GEF) and the CGIAR Research Program on Climate Change, Agriculture and Food Security (CCAFS). Thanks also to the CGIAR Research Program on Aquatic Agricultural Systems for funding this ex-ante assessment, and to SEI's initiative on Transforming Development and Disaster Risk (with funds provided by the Swedish government) for additional support. Without the assistance of many colleagues and in-country partners this research could not have been undertaken and special thanks to Kirsten Abernethy, Douglas Beare, Philippa Cohen, Jennifer King, Dave Mills, Sharon Suri, Nhuong Tran, Hugh Govan, Delvene Boso, Daykin Harohau and the other members of the WorldFish Solomon Islands team, as well as representatives of the Governments and local NGOs of TimorLeste and Solomon Islands, particular Roman Luan.

\section{References}

Agrawal, A., (2010). Local institutions and adaptation to climate change, in: Mearns, R., Norton, A. (Eds.), Social Dimensions of Climate Change: Equity and Vulnerability in a Warming World. World Bank, Washington DC, pp. 173-198.

Angeler, D.G. and Allen, C.R. (2016). EDITORIAL: Quantifying resilience. Journal of Applied Ecology, 53(3), 617-624.

Apgar, M. J., Allen, W., Moore, K., \& Ataria, J. (2015). Understanding adaptation and transformation through indigenous practice: the case of the Guna of 
Panama. Ecology and Society, 20(1). http://doi.org/10.5751/ES-07314200145

Armitage, D., Marschke, M., Plummer, R., (2008). Adaptive co-management and the paradox of learning. Global Environmental Change, 18, 86-98. doi:10.1016/j.gloenvcha.2007.07.002

Armitage, D., Berkes, F., Dale, A., Kocho-Schellenberg, E., Patton, E., (2011). Comanagement and the co-production of knowledge: Learning to adapt in Canada's Arctic. Global Environmental Change, 21, 995-1004. doi:10.1016/j.gloenvcha.2011.04.006

Artur, L., Hilhorst, D., (2012). Everyday realities of climate change adaptation in Mozambique. Global Environmental Change, 22, 529-536. doi:10.1016/j.gloenvcha.2011.11.013

Ayers, J., (2011). Resolving the Adaptation Paradox: Exploring the Potential for Deliberative Adaptation Policy-Making in Bangladesh. Global Environmental Politics, 11, 62-88. doi:10.1111/j.1759-5436.2008.tb00472.x

Ayers, J., Forsyth, T., (2009). Community based adaptation to climate change: strengthening resilience through development. Environment: Science and Policy for Sustainable Development, 51, 22-31.

Bahadur, A.V., Ibrahim, M., Tanner, T., (2013). Characterising resilience: unpacking the concept for tackling climate change and development. Climate and Development, 1-11. doi:10.1080/17565529.2012.762334

Bassett, T.J., Fogelman, C., (2013). Déjà vu or something new? The adaptation concept in the climate change literature. Geoforum, 48, 42-53. doi:10.1016/j.geoforum.2013.04.010

Berger, R., Ensor, J., Wilson, K., Phukan, I., Dasgupra, S., (2014). Adaptive Capacity, in: Schipper, E.L., Ayers, J., Reid, H., Huq, S., Rahman, A. (Eds.), Community-Based Adaptation to Climate Change: Scaling It Up. Earthscan, pp. 22-35.

Berkes, F., (2007). Community-based conservation in a globalized world. Proceedings of the National Academy of Sciences, 104, 15188-15193. doi:10.1073/pnas.0702098104

Berkes, F., Ross, H., (2013). Community Resilience: Toward an Integrated Approach. Society \& Natural Resources, 26, 5-20. doi:10.1080/08941920.2012.736605

Béné, C., Newsham, A., Davies, M., Ulrichs, M., Godfrey-Wood, R., (2014). Resilience, Poverty and Development. Journal of International Development, n/a-n/a. doi:10.1002/jid.2992

Biermann, M., Hillmer-Pegram, K., Knapp, C.N., Hum, R.E., (2015). Approaching a critical turn? A content analysis of the politics of resilience in key bodies of resilience literature. Resilience 1-20. doi:10.1080/21693293.2015.1094170

BirdLife International (2015) Important Bird Areas factsheet: Prek Toal. Downloaded from http://www.birdlife.org on 20/03/2015.

Castine, S. A., Sellamuttu, S. S., Cohen, P., Chandrabalan, D., Phillips, M. (2013). Increasing productivity and improving livelihoods in aquatic agricultural systems: A review of interventions. WorldFish. AAS-2013-30.

CGIAR (2012). CGIAR research program on aquatic agricultural systems: Program proposal. Penang, Malaysia: WorldFish. AAS-2012-07.

Borrini-Feyerabend, G., Pimbert, M., Farvar, M., Kothari, A., Renard, Y., (2004). Sharing Power. Learning by doing in co-management of natural resources 
throughout the world. IIED and IUCN/CEESP/CMWG.

Boyd, E., Folke, C. (Eds.) (2011). Adapting Institutions. Cambridge University Press, Cambridge.

Broto, V.C., Boyd, E., Ensor, J., (2015). Participatory urban planning for climate change adaptation in coastal cities: lessons from a pilot experience in Maputo, Mozambique. Current Opinion in Environmental Sustainability, 13, 11-18. doi:10.1016/j.cosust.2014.12.005

Brown, K., (2011). Sustainable adaptation: An oxymoron? Climate and Development, 3, 21-31. doi:10.3763/cdev.2010.0062

Brown, K., (2014). Global environmental change I: A social turn for resilience? Progress in Human Geography, 38, 107-117. doi:10.1177/0309132513498837

Brown, K., Westaway, E., (2011). Agency, Capacity, and Resilience to Environmental Change: Lessons from Human Development, Well-Being, and Disasters. Annu. Rev. Environ. Resourc., 36, 321-342. doi:10.1146/annurevenviron-052610-092905

Brunner, R.D., Lynch, B., (2010). Adaptive Governance and Climate Change. American Meteorolgical Society/ University of Chicago Press, Chicago.

Butler, J., Suadnya, W., Puspadi, K., Sutaryono, Y., (2013). Framing the application of adaptation pathways for rural livelihoods and global change in eastern Indonesian islands. Global Environmental Change, 28, 368-382.

Cash, D.W., (2006). Countering the Loading-Dock Approach to Linking Science and Decision Making: Comparative Analysis of El Nino/Southern Oscillation (ENSO) Forecasting Systems. Science, Technology \& Human Values, 31, 465494. doi:10.1177/0162243906287547

Cash, D.W., Clark, W.C., Alcock, F., Dickson, N.M., Eckley, N., Guston, D.H., Jager, J., Mitchell, R.B., (2003). Knowledge systems for sustainable development. Proceedings of the National Academy of Sciences, 100, 8086-8091. doi:10.1073/pnas.1231332100

Chapin, F.S., Lovecraft, A.L., Zavaleta, E.S., Nelson, J., Robards, M.D., Kofinas, G.P., Trainor, S.F., Peterson, G.D., Huntington, H.P., Naylor, R.L., (2006). Inaugural Article: Policy strategies to address sustainability of Alaskan boreal forests in response to a directionally changing climate. Proceedings of the National Academy of Sciences, 103, 16637-16643. doi:10.1073/pnas.0606955103

Cheshire, L. (2015). "Know your neighbours": disaster resilience and the normative practices of neighbouring in an urban context. Environment and Planning A, 47(5), 1081-1099. http://doi.org/10.1177/0308518X15592310

Collins, K., Ison, R., (2009). Editorial: living with environmental change: adaptation as social learning. Env. Pol. Gov., 19, 351-357. doi:10.1002/eet.520

Cote, M., Nightingale, A.J., (2012). Resilience thinking meets social theory: Situating social change in socio-ecological systems (SES) research. Progress in Human Geography 36, 475-489. doi:10.1177/0309132511425708

Davidson, D.J., (2013). We Still Have a Long Way to Go, and a Short Time to Get There: A Response to Fikret Berkes and Helen Ross. Society \& Natural Resources, 26, 21-24. doi:10.1080/08941920.2012.749758

Davies, J., Robinson, L. W., \& Ericksen, P. J. (2015). Development Process Resilience and Sustainable Development: Insights from the Drylands of Eastern Africa. Society \& Natural Resources. 
http://doi.org/10.1080/08941920.2014.970734

Dodman, D., Mitlin, D., (2011). Challenges for community-based adaptation: discovering the potential for transformation. Journal of International Development, 25(5), 640-659. doi:10.1002/jid.1772

Dodman, D., Mitlin, D., (2014). The national and local politics of climate change adaptation in Zimbabwe. Climate and Development, 1-12. doi:10.1080/17565529.2014.934777

Eade, D., (2010). Capacity building: who builds whose capacity?, in: Cornwall, A., Eade, D. (Eds.), Deconstructing Development Discourse. Practical Action Publishing, Rugby, pp. 203-214.

Eakin, H., Lemos, M.C., (2010). Institutions and change: The challenge of building adaptive capacity in Latin America. Global Environmental Change, 20, 1-3. doi:10.1016/j.gloenvcha.2009.08.002

Ebi, K.L., Semenza, J.C., (2008). Community-Based Adaptation to the Health Impacts of Climate Change. American Journal of Preventive Medicine, 3, 501507

Ensor, J., (2011). Uncertain Futures. Practical Action Publishing, Rugby.

Ensor, J., (2014). Emerging lessons for community-based adaptation, in: Ensor, J., Berger, R., Huq, S. (Eds.), Community-Based Adaptation to Climate Change. Emerging Lessons. Practical Action Publishing, Rugby, pp. 183-197.

Ensor, J., Berger, R., Huq, S. (Eds.) (2014). Community-Based Adaptation to Climate Change. Emerging Lessons. Practical Action Publishing, Rugby.

Ensor, J., Berger, R., (2009). Understanding climate change adaptation. Practical Action Publishing, Rugby.

Ensor, J.E., Park, S.E., Hoddy, E.T., Ratner, B.D., (2015). A rights-based perspective on adaptive capacity. Global Environmental Change, 31, 38-49. doi:10.1016/j.gloenvcha.2014.12.005

Fainstein, S. (2015). Resilience and Justice. International Journal of Urban and Regional Research, 39(1), 157-167. http://doi.org/10.1111/14682427.12186

Folke, C., (2003). Freshwater for resilience: a shift in thinking. Philosophical Transactions of the Royal Society B: Biological Sciences, 358, 2027-2036. doi:10.1098/rstb.2003.1385

Folke, C., (2006). Resilience: The emergence of a perspective for social-ecological systems analyses. Global Environmental Change, 16, 253-267. doi:10.1016/j.gloenvcha.2006.04.002

Folke, C., Hahn, T., Olsson, P., Norberg, J., (2005). Adaptive Governance of SocialEcological Systems. Annu. Rev. Environ. Resourc., 30, 441-473. doi:10.1146/annurev.energy.30.050504.144511

Chung Tiam Fook, T. (2015). Transformational processes for community-focused adaptation and social change: a synthesis. Climate and Development, 1-17. http://doi.org/10.1080/17565529.2015.1086294

Forsyth, T., (2013). Community-based adaptation: a review of past and future challenges. WIREs Climate Change, 4, 439-446. doi:10.1002/wcc.231

Frankenberger, T.R., Constas, M.A., Nelson, S., Starr, L., (2014). Current approaches to resilience programming among nongovernmental organizations, in:. Presented at the Building Resilience for Food and Nutrition Security. 
Govan, H., Schwarz, A.M., Harohau, D., Oeta, J. (2013a). Solomon Islands National Situation Analysis. CGIAR Research Program on Aquatic Agricultural Systems. Penang, Malaysia. Project Report: AAS-2013-16.

Govan, H., Schwarz, A.M., Harohau, D., Oeta, J., Orirana, G., Ratner, B. D. (2013b). Solomon Islands: Essential aspects of governance for Aquatic Agricultural Systems in Malaita Hub. Penang, Malaysia. PR AAS-2013-19. http://aas.cgiar.org/content/solomon-islands-essential-aspectsgovernance-aquatic-agricultural-systems-malaitahubhttp://aquaticcommons.org/11219/1/AAS-2013-16.pdf

Granderson, A.A., (2014). Making sense of climate change risks and responses at the community level: a cultural-political lens. Climate Risk Management. doi:10.1016/j.crm.2014.05.003

Gupta, J., Termeer, C., Klostermann, J., Meijerink, S., van den Brink, M., Jong, P., Nooteboom, S., Bergsma, E., (2010). The Adaptive Capacity Wheel: a method to assess the inherent characteristics of institutions to enable the adaptive capacity of society. Environmental Science and Policy, 1-13. doi:10.1016/j.envsci.2010.05.006

Heltberg, R., Gitay, H., Prabhu, R.G., (2012). Community-based adaptation: lessons from a grant competition. Climate Policy, 12, 143-163. doi:10.1080/14693062.2011.582344

Ingalls, M., \& Stedman, R. (2016). The power problematic: exploring the uncertain terrains of political ecology and the resilience framework. Ecology and Society, 21(1), art6. http://doi.org/10.5751/ES-08124-210106

ISET, (2010). The shared learning dialogue: Building stakeholder capacity and engagement for resilience action. climate resilience in concept and practice. Working Paper Series, Boulder, CO, USA.

IUCN (2014). A guiding toolkit for increasing climate change resilience. Regional Office for West Asia. https://cmsdata.iucn.org/downloads/ iucn_report_3_pdf (Accessed 18 March 2015).

Kanji, N., Tan, S.U., (2008). Understanding local difference: gender (plus) matters for NGOs. Participatory Learning and Action, 72-81.

Lave, J., Wenger, E., (1991). Situated Learning. Cambridge University Press, Cambridge, UK.

Letourneau, D K., Armbrecht, I., Rivera, B. S., Lerma, J. M., Jiménez Carmona, E., Daza, M. C., Escobar S., (2011). Does plant diversity benefit agroecosystems? A synthetic review. Ecological Applications, 21(1):9-21.

Ludi, E., Jones, L., Levine, S., (2012). Changing focus? How to start taking adaptive capacity seriously (No. Briefing Paper 71). Overseas Development Institute.

Ludi, E., Wiggins, S., Jones, L., Lofthouse, J., Levine, S., (2014). Adapting development: how wider development interventions can support adaptive capacity at the community level, in: Community-Based Adaptation to Climate Change: Scaling It Up. Routledge, London, pp. 36-52.

MacKinnon, D., Derickson, K.D., (2013). From resilience to resourcefulness: A critique of resilience policy and activism. Progress in Human Geography, 37, 253-270. doi:10.1177/0309132512454775

Madzudzo, E., Mulanda, A., Nagoli, J., Lunda, J., Ratner, B.D. (2013). A Governance Analysis of the Barotse Floodplain System, Zambia: Identifying Obstacles and Opportunities. CGIAR Research Program on Aquatic Agricultural Systems. Penang, Malaysia. Project Report: AAS-2013-26. 
Mallett, R., Hagen-Zanker, J., Slater, R., Duvendack, M., (2012). The benefits and challenges of using systematic reviews in international development research. Journal of Development Effectiveness, 4, 445-455. doi:10.1080/19439342.2012.711342

Marshall, N.A., Park, S., Howden, S.M., Dowd, A.B., Jakku, E.S., (2013). Climate change awareness is associated with enhanced adaptive capacity. Development Policy Review. doi:10.1016/j.agsy.2013.01.003

Mills, D.J., Abernethy, K.A., King, J., Hoddy, E.T., Teoh, S.J., Larocca, P., Gonsalves, D., Fernandes, A., and Park, S.E. (2013). Developing Timor-Leste's coastal economy: Assessing potential climate change impacts and adaptation options. Final report to the Australian Government Coral Triangle Initiative on Coral Reefs, Fisheries and Food Security National Initiative. WorldFish, Penang, Malaysia.

Mitchell, T., Tanner, T., (2006). Adapting to Climate Change. Institute of Development Studies and Tearfund.

Munang, R., Thiaw, I., Alverson, K., Mumba, M., Liu, J., Rivington, M., (2013). Climate change and Ecosystem-based Adaptation: a new pragmatic approach to buffering climate change impacts. Current Opinion in Environmental Sustainability, 5, 67-71.

Nelson, D.R., Adger, W.N., Brown, K., (2007). Adaptation to Environmental Change: Contributions of a Resilience Framework. Annu. Rev. Environ. Resourc., 32, 395-419. doi:10.1146/annurev.energy.32.051807.090348

O'Brien, K., (2012). Global environmental change II: From adaptation to deliberate transformation. Progress in Human Geography, 36, 667-676. doi:10.1177/0309132511425767

Paavola, J., Adger, W.N., (2006). Fair adaptation to climate change. Ecological Economics, 56, 594-609. doi:10.1016/j.ecolecon.2005.03.015

Park, S., Abernethy, K., Attwood, J.S., Beare, D., Cohen, P., Govan, H., King, J., Mills, D., Timmers, B., Tran, N., Suri, S., (2012). Responding to climate change using an adaptation pathways and decision-making approach (No. Mid- term project report for ADB/GEF project R-CDTA 7753.). The WorldFish Centre.

Pauwelussen, A. (2016). Community as network: exploring a relational approach to social resilience in coastal Indonesia. Maritime Studies, 15(2). http://doi.org/10.1186/s40152-016-0041-5

Pelling, M., (2011). Adaptation to Climate Change. Routledge.

Pelling, M., O'Brien, K., Matyas, D., (2014). Adaptation and transformation. Climatic Change. doi:10.1007/s10584-014-1303-0

Plummer, R., (2013). Can Adaptive Comanagement Help to Address the Challenges of Climate Change Adaptation? Ecology and Society, 18.

Pradhan, N.S., Schipper, L., Khadgi, V., Kaur, N., Geoghegan, T., (2012). Role of policy and institutions in local adaptation to climate change: Case studies on responses to too much and too little water in the Hindu Kush Himalayas. ICIMOD.

Pringle, P., Conway, D., (2012). Voices from the frontline: the role of communitygenerated information in delivering climate adaptation and development objectives at project level. Climate and Development, 4, 104-113. doi:10.1080/17565529.2012.707608

Ratner, B. D., Cohen, P., Barman, B., Mam, K., Nagoli, J., \& Allison, E. H. (2013). Governance of aquatic agricultural systems: analyzing representation, power, and accountability. Ecology and Society, 18(4), 59. 
Rawlani, A.K., Sovacool, B.K., (2011). Building responsiveness to climate change through community based adaptation in Bangladesh. Mitig Adapt Strateg Global Change, 16, 845-863. doi:10.1007/s11027-011-9298-6

Reed, M.S., Evely, A.C., Cundill, G., Fazey, I., Glass, J., Laing, A., Newig, J., Parrish, B., Prell, C., Raymond, C., Stringer, L.C., (2010). What is Social Learning? Ecology and Society, 15.

Reid, H., Alam, M., Berger, R., Cannon, T., (2009). Community-based adaptation to climate change. Participatory Learning and Action, 60, 11-33.

Robinson, G. M., \& Carson, D. A. (2015). Resilient communities: transitions, pathways and resourcefulness. The Geographical Journal, 182(2), 114-122. http://doi.org/10.1111/geoj.12144

Ross, H., Berkes, F., (2013). Community Resilience: A Rejoinder to Debra J. Davidson. Society \& Natural Resources, 26, 25-29. doi:10.1080/08941920.2012.749769

Schiffer, E., Hauck, J., (2010). Net-Map: Collecting Social Network Data and Facilitating Network Learning through Participatory Influence Network Mapping. Field Methods, 22, 231-249. doi:10.1177/1525822X10374798

Schipper, E.L.F., Ayers, J., Reid, H., Huq, S., Rahman, A., (2014). Community-Based Adaptation to Climate Change. Routledge.

Schwarz, A.M., Andrew, N., Govan, H., Harohau, D., Oeta, J. (2013). Solomon Islands Malaita Hub Scoping Report. CGIAR Research Program on Aquatic Agricultural Systems. Penang, Malaysia Project Report.

Simane, B., (2013). The Sustainability of Community-Based Adaptation in the Choke Mountain Watersheds, Blue Nile Highlands, Ethiopia. Sustainability, 5.

Shaw, R., (2006). Community-based climate change adaptation in Vietnam: inter-linkages of environment, disaster, and human security, in: Multiple Dimension of Global Environmental Changes, S. Sonak (ed), TERI publication, New Delhi, 521-547.

Sjöstedt, M. (2015). Resilience revisited: taking institutional theory seriously. Ecology and Society, 20(4), 23.

Smit, B., Wandel, J., (2006). Adaptation, adaptive capacity and vulnerability. Global Environmental Change, 16, 282-292. doi:10.1016/j.gloenvcha.2006.03.008

Spires, M., Shackleton, S., Cundill, G., (2014). Barriers to implementing planned community-based adaptation in developing countries: a systematic literature review. Climate and Development, 6, 277-287. doi:10.1080/17565529.2014.886995

Tongway, D.J., Hindley, N.L., (2004). Landscape Function Analysis Manual: Procedures for Monitoring and Assesssing Landscapes with Special Reference to Minesites and Rangelands, 3rd ed. CSIRO Sustainable Ecosystems.

Toledo, Á., \& Burlingame, B., (2006). Biodiversity and nutrition: A common path toward global food security and sustainable development. Journal of Food Composition and Analysis, 19(6), 477-483.

UNU-IAS, Bioversity International, IGES and UNDP (2014). Toolkit for the Indicators of Resilience in Socioecological Production Landscapes and Seascapes (SEPLS).

Walker, B., Gunderson, L., Kinzig, A., Folke, C., Carpenter, S., Schultz, L., (2006). A handful of heuristics and some propositions for understanding resilience in 
social-ecological systems. Ecology and Society, 11(1), 13.

Walker, B.H., Salt, D.A., (2006). Resilience thinking. Island Pr.

Wise, R.M., Fazey, I., Stafford Smith, M., Park, S.E., Eakin, H.C., Archer Van Garderen, E.R.M., Campbell, B., (2014). Reconceptualising adaptation to climate change as part of pathways of change and response. Global Environmental Change. doi:10.1016/j.gloenvcha.2013.12.002

World Bank, (2015). http://data.worldbank.org/country/timor-leste

Yates, J., (2014). Power and politics in the governance of community based adaptation, in: Ensor, J.E., Berger, R., Huq, S. (Eds.), Community-Based Adpation to Climate Change: Emerging Lessons. Practical Action Publishing, Rugby.

Yates, J.S., (2012). Uneven interventions and the scalar politics of governing livelihood adaptation in rural Nepal. Global Environmental Change, 22, 537546. doi:10.1016/j.gloenvcha.2012.01.007

Quinlan, A.E., Berbés-Blázquez, M., Haider, L.J. and Peterson, G.D., (2015). Measuring and assessing resilience: broadening understanding through multiple disciplinary perspectives. Journal of Applied Ecology. 
Table 3. Relating CBA assessment tools to resilience characteristics. Based on the assessment above and using expert opinion provided by two of the co-authors who were CBA case study implementers, an estimate was made of the relative contribution of each tool to the characteristic in the case studies (white - low contribution; grey - medium contribution; black - high contribution).

\begin{tabular}{|c|c|c|c|c|c|c|c|c|c|c|}
\hline & $\begin{array}{c}\text { High } \\
\text { Diversity }\end{array}$ & $\begin{array}{c}\text { Effective } \\
\text { governance/ } \\
\text { institutions }\end{array}$ & $\begin{array}{l}\text { Acceptance } \\
\text { of } \\
\text { uncertainty } \\
\text { and change }\end{array}$ & $\begin{array}{l}\text { Non- } \\
\text { equilibrium } \\
\text { system } \\
\text { dynamics }\end{array}$ & $\begin{array}{l}\text { Community } \\
\text { involvement } \\
\text { and inclusion } \\
\text { of local } \\
\text { knowledge }\end{array}$ & $\begin{array}{l}\text { Preparedness } \\
\text { and planning }\end{array}$ & $\begin{array}{l}\text { High degree } \\
\text { of equity }\end{array}$ & $\begin{array}{c}\text { Social capital, } \\
\text { values, and } \\
\text { structures }\end{array}$ & Learning & $\begin{array}{l}\text { Adoption of a } \\
\text { cross-scalar } \\
\text { perspective }\end{array}$ \\
\hline Climate analysis & & & & & & & & & & \\
\hline $\begin{array}{l}\text { Impact \& } \\
\text { adaptation } \\
\text { workshop }\end{array}$ & & & & & & & & & & \\
\hline $\begin{array}{l}\text { Decision-tree } \\
\text { and partial cost } \\
\text { benefit analysis }\end{array}$ & & & & & & & & & & \\
\hline $\begin{array}{l}\text { Social network } \\
\text { analysis }\end{array}$ & & & & & & & & & & \\
\hline $\begin{array}{l}\text { Governance } \\
\text { analysis }\end{array}$ & & & & & & & & & & \\
\hline $\begin{array}{l}\text { Landscape } \\
\text { Function } \\
\text { Analysis }\end{array}$ & & & & & & & & & & \\
\hline $\begin{array}{l}\text { Ecosystem } \\
\text { service } \\
\text { mapping }\end{array}$ & & & & & & & & & & \\
\hline $\begin{array}{l}\text { Implementation } \\
\text { planning }\end{array}$ & & & & & & & & & & \\
\hline
\end{tabular}

